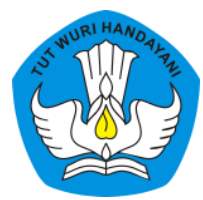

Page: 109-124

\title{
PENGEMBANGAN MODUL ETNOMATEMATIKA BERBASIS BUDAYA DAYAK DALAM PEMBELAJARAN MATEMATIKA DENGAN PENDEKATAN JOYFULL LEARNING
}

\author{
Niken Eka Priyani \\ Sekolah Dasar Negeri 29 Idai, Kalimantan Barat, Indonesia \\ Contributor Email: nikensuka@gmail.com
}

Received: Jan 21, 2021

Accepted: Mar 9, 2021

Published: Mar 30, 2021

Article Url: https://ojsdikdas.kemdikbud.go.id/index.php/didaktika/article/view/226

\begin{abstract}
The conditions of the Covid-19 pandemic caused learning to change to once a week, limited teaching materials at SDN 29 Idai, and a decrease in the values of preserving Dayak culture in Idai village. Through the integration of the concepts of mathematics and culture, this study aims to develop an ethno-mathematics module based on the Dayak culture in mathematics learning with a joyful learning approach. This research is a research development or Research and Development $(R \mathcal{E} D)$ with a research method using the Hanafin $\mathcal{E}$ Peck development model which focuses on solving problems of quality constraints and development complexity which consists of three stages, namely; 1) needs assessment; 2) the design stage; and 3) development and evaluation. The data collection technique used observation, interview, and ethnomatematics module validation sheets which were filled in by two reviewers, while module trials were conducted in grade 4 SDN 29 Idai. The results showed that the ethno-mathematics module based on the Dayak culture with a joyful learning approach got good results, so that it could be used to teach math concepts to grade 4 students at SDN 29 Idai.
\end{abstract}

Keywords: Ethnomatematics Module; Dayak Culture; Joyfull Learning 


\begin{abstract}
Abstrak
Kondisi pandemi Covid-19 menyebabkan pembelajaran berubah menjadi satu kali dalam seminggu, keterbatasan bahan ajar di SDN 29 Idai, serta penurunan nilainilai pelestarian budaya Dayak terjadi di Desa Idai. Melalui integrasi konsep matematika dan budaya maka penelitian ini bertujuan untuk mengembangkan modul etnomatematika berbasis budaya Dayak dalam pembelajaran matematika dengan pendekatan joyfull learning. Penelitian ini merupakan penelitian pengembangan atau Reseach and Development $(R \in \mathcal{E} D)$ dengan metode penelitian menggunakan model pengembangan Hanafin $\mathcal{E}$ Peck yang berfokus pada pemecahan masalah kendala kualitas dan kompleksitas pengembangan yang terdiri dari tiga tahapan yakni; 1) penilaian kebutuhan; 2) tahap desain; dan 3) pengembangan dan evaluasi. Teknik pengumpulan data menggunakan teknik observasi, wawancara, dan lembar validasi modul etnomatematika yang diisi oleh dua orang reviewer, sedangkan uji coba modul dilakukan di kelas 4 SDN 29 Idai. Hasil penelitian menunjukkan bahwa modul etnomatematika berbasis budaya Dayak dengan pendekatan joyfull learning mendapatkan hasil yang baik, sehingga dapat digunakan untuk mengajarkan konsep matematika bagi siswa kelas 4 di SDN 29 Idai.
\end{abstract}

Kata Kunci: Modul Etnomatematika; Budaya Dayak; Joyfull learning.

\title{
A. Pendahuluan
}

Sebagai usaha pencegahan penyebaran Covid-19 di Indonesia serta menjalankan rekomendasi dari WHO untuk menghentikan sementara kegiatan-kegiatan yang berpotensi menimbulkan kerumunan massa, Kemendikbud mengeluarkan Surat Edaran (SE) Nomor 4 Tahun 2020 tentang Pelaksanaan Pelaksanaan Kebijakan Pendidikan dalam Masa Darurat Penyebaran Covid-19. Dalam SE tersebut antara lain diatur tentang (1) pembatalan UN dan UKK tahun 2020; (2) siswa tidak dibebani tuntutan menuntaskan seluruh capaian kurikulum dan memfokuskan pada pendidikan kecakapan hidup, melaksanakan pembelajaran jarak jauh dengan menyesuaikan minat, kondisi siswa, serta akses dan fasilitas belajar di rumah; (3) Pemerintah melarang pengadaan ujian dengan mengumpulkan siswa, sebaliknya menegaskan perlunya mengubah pembelajaran menjadi daring; (4) melaksanakan PPDB 2020 dengan mengikuti protokol kesehatan; (5) penggunaan BOS dan BOP untuk 
pembiayaan pencegahan pandemi Covid-19 seperti penyediaan hand sanitizer, disinfectant dan masker (Muhammad, 2020).

Kondisi pandemi ini juga menyebabkan pembelajaran di SDN 29 Idai menjadi terpengaruh. Pembelajaran tatap muka yang selama ini dilakukan setiap hari, berubah menjadi tatap muka seminggu sekali. Namun karena banyaknya warga Indonesia di Desa Idai yang pulang dari Negara Malaysia serta untuk mencegah penularan virus Covid-19 maka pembelajaran diubah menjadi daring. Anugrahana (2020) menyatakan bahwa dalam masa pandemic Covid-19, pihak sekolah mulai mengubah strategi pembelajaran yang awalnya tatap muka menjadi pembelajaran nontatap muka atau yang juga disebut pembelajaran online atau pembelajaran jarak jauh.

Pembelajaran online tidak dapat dilaksanakan secara maksimal di SDN 29 Idai karena banyaknya siswa yang tidak memiliki perangkat handphone untuk belajar online. Sebagian besar orang tua siswa berladang di kebun dan bekerja di perkebunan sawit. Hal ini menyebabkan siswa harus belajar sendiri di rumah. Berdasarkan hasil pengamatan selama masa pandemi, siswa lebih banyak bermain serta banyak siswa yang mulai melupakan nilai-nilai budaya yang diterapkan di dalam masyakat Dayak. Hal ini dikarenakan selama masa pandemi Covid-19 kegiatan kebudayaan atau perlombaan ditiadakan karena kegiatan itu melibatkan banyak orang. Tradisi penyambutan tamu menggunakan tarian adat juga tidak dapat dilaksanakan siswa SDN 29 Idai jika ada tamu penting datang untuk berkunjung ke desa. Di lain pihak, siswa lebih suka berkumpul dan bermain dari pada mengerjakan tugas. Jika hal ini dibiarkan maka budaya dan tradisi Dayak akan luntur karena pengaruh modernisasi serta kondisi pandemi Covid-19 memperparah hal tersebut. Hal ini sejalan dengan pendapat Haran, Hartoyo, \& Sayu ( 2019) yang menyatakan bahwa pendidikan dan budaya memiliki peran yang sangat penting dalam menumbuhkan dan mengembangkan nilai kebudayaan, yang berdampak pada pembentukan karakter yang didasarkan pada nilai budaya yang dimiliki. Hammond dalam Haran, Hartoyo, \& Sayu (2018) mengungkapkan bahwa 
setiap budaya tampaknya memiliki perhitungan, penyusunan, dan dasardasar matematika lainnya, yang tampaknya menyiratkan sesuatu yang mendasar dan kuat tentang dasar-dasar matematika.

Konsep pembelajaran yang menarik dan menyenangkan dalam mengajarkan konsep-konsep matematika di masa pandemi Covid-19 perlu dilakukan dengan mempertimbangkan aspek-aspek lokal yang berkembang dalam masyarakat di sekitar lingkungan siswa. Terkait dengan hal ini Hartoyo (2012) yang menyatakan bahwa salah satu tujuan belajar matematika adalah membentuk skemata baru dalam struktur kognitif dengan mempertimbangkan skemata anak sehingga terjadi asimilasi. Pembelajaran matematika yang menarik dan menyenangkan, diharapkan dapat mempermudah siswa dalam mengaitkan antara pengetahuan awal siswa dengan pemahaman konteks di lingkungannya, sehingga pembelajaran lebih mudah diterima oleh siswa, mudah diingat dan bermakna bagi siswa. Hal ini sesuai dengan pendapat Prinotama, Larasati, \& Roosyanti (2019) yang menyatakan bahwa pembelajaran Joyfull Learning adalah pembelajaran yang di dalamnya terdapat keterkaitan antara pendidik dan peserta didik dimana penciptaan lingkungan pembelajaran yang dibuat menyenangkan dan merangsang anak untuk belajar dengan suasana kelas yang diciptakan penuh kegembiraan sehingga membawa kegembiraan pula dalam belajar.

SDN 29 Idai adalah sekolah yang terletak di pedalaman Kabupaten Sintang yang berbatasan dengan Negara Malaysia. Akses transportasi yang sulit dan belum adanya listrik dari PLN merupakan sebagian masalah yang dialami guru dan siswa-siswa di SDN 29 Idai. Selama masa pandemi Covid-19, pembelajaran menjadi tidak maksimal. Hal ini juga diperparah dengan kurangnya bahan ajar matematika di sekolah. Kondisi yang dialami sejalan dengan kondisi sekolah dasar yang berada di lokasi daerah 3T yang selalu terkendala kurangnya bahan ajar (Apriyono et al., 2019; Firmansyah \& Haris, 2019). Pembuatan bahan ajar Etnomatematika yang mudah dipahami, menarik, dan dapat digunakan siswa untuk belajar di rumah selama masa pandemi Covid-19 dengan mengaitkan budaya masyarakat Dayak menjadi sebuah solusi 
yang dilakukan guru di tengah keterbatasan. Etnomatematika merupakan matematika yang dipraktikkan oleh kelompok budaya seperti masyarakat perkotaan dan pedesaan, kelompok buruh, anak-anak dari kelompok usia tertentu, masyarakat adat, dan lainnya (Apriyono et al., 2019). Hal ini sejalan dengan pendapat Firmansyah \& Haris (2019) bahwa integrasi etnomatematika pada pembelajaran dapat dilakukan oleh pendidik dengan membuat bahan ajar bernuansa etnomatematika. Maka, pengembangan bahan ajar etnomatematika bagi siwa sekolah dasar memerlukan keterampilan guru dalam memadukan konsep budaya dayak dan konsep matematika di SDN 29 Idai.

Pembelajaran Etnomatematika menuntut adanya analisis terhadap konsep budaya, konsep matematika yang akan diajarkan, serta kondisi lingkungan setempat (Prayitno, Rachmiaszasi, \& Kadarwati, 2017). Analisis perlu dilakukan karena etnomatika tidak dapat dilaksanakan secara terusmenerus sehingga analisis konsep matematika sangat diperlukan agar siswa mudah memahami konsep matematika yang disampaikan. Adanya keterkaitan materi matematika di sekolah dasar dengan lingkungan siswa dapat meningkatkan kepercayaan diri siswa dalam mengikuti proses pembelajaran di sekolah dasar (Prayitno et al., 2017).

Berdasarkan latar belakang tersebut, tujuan penelitian ini adalah untuk mendeskripsikan bagaimana pengembangan modul pembelajaran Etnomatematika berbasis budaya Dayak dengan pendekatan joyfull learning bagi siswa SDN 29 Idai selama masa pandemi Covid-19.

\section{B. Metode}

Metode penelitian yang digunakan adalah metode penelitian pengembangan dengan menggunakan model pengembangan Hanafin $\mathcal{E}$ Peck. Model Hannafin $\mathcal{E}$ Peck digunakan peneliti dalam pembuatan "Modul Etnomatematika Berbasis Budaya Dayak dalam Pembelajaran Matematika dengan Pendekatan Joyfull Learning" (dalam Krishna, Agustini, \& Tegeh, 2018). Model pengembangan Hannafin \& Peck merupakan model yang sederhana karena model ini berfokus pada 
pemecahan masalah kendala kualitas dan kompleksitas pengembangan yang terdiri dari tiga tahapan yakni (1) penilaian kebutuhan, (2) tahap desain, serta (3) pengembangan dan evaluasi. Pada model pengembangan ini, ketiga tahapan terhubung pada kegiatan "evaluasi dan revisi" yang merupakan tahap yang sangat penting dalam penyempurnaan perangkat pembelajaran pada ketiga tahapan inti (Tegeh, 2020)

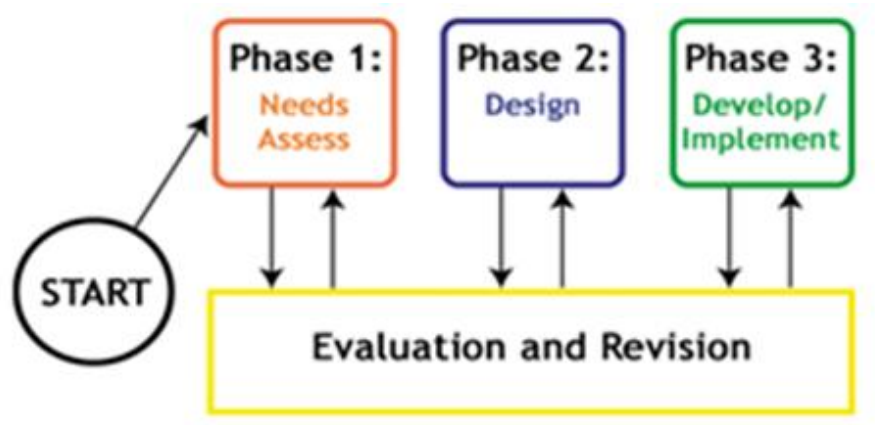

Gambar 1. Tahapan Model Pengembangan Hannafin \& Peck (Krishna, Agustini, \& Tegeh, 2018)

Tahap pertama adalah tahap penilaian kebutuhan. Pada tahap penilaian kebutuhan ini dilakukan analisis, yang terdiri dari (1) analisis permasalahan pembelajaran (instructional problem analysis), (2) analisis pembelajar (audience analysis), (3) analisis tujuan (goals analysis), dan (4) analisis setting pembelajaran (instructional setting analysis).

Tahap kedua adalah tahap desain. Pada tahap desain, pembuatan Modul Etnomatematika, telah dilakukan studi literasi sebelumnya terhadap berbagai modul dan buku BSE Matematika kelas 4 sebagai acuan dalam mengembangkan sebuah modul yang baik dan sesuai dengan tujuan yang ingin dicapai.

Tahap ketiga adalah tahap pengembangan dan implementasi. Tahapan ini lebih mencakup kepada kegiatan pengumpulan dokumen berupa foto-foto bagunan dan aktivitas warga Dayak di Desa Idai, Kabupaten Sintang, Provinsi Kalimantan Barat untuk dijadikan bahan dalam pembuatan Modul Etnomatematika Berbasis Budaya Dayak 
dengan Pendekatan Joyfull Learning. Tahap review dilakukan oleh dosen Program Studi Pendidikan Matematika IKIP PGRI Pontianak untuk mendapatkan masukan dan saran perbaikan pengembangan produk sebelum diimplementasikan.

Kegiatan implementasi penggunaan produk dilakukan di kelas 4 SD Negeri 29 Idai, Kabupaten Sintang Provinsi Kalimantan Barat secara Luring dengan melakukan tatap muka sekali (satu kali) dalam seminggu, kemudian guru membagikan Modul Etnomatematika berbasis budaya Dayak dengan pendekatan Joyfull Learning kepada siswa. Selanjutnya guru meminta siswa mengerjakan modul di rumah masing-masing sebagai bahan belajar selama kegiatan pembelajaran di masa pandemi Covid-19 di SDN 29 Idai Kabupaten SIntang. Pengumpulan dan pembahasan dilakukan di sekolah bersama dengan guru.

Tahap keempat adalah tahap evaluasi dan revisi. Tahap evaluasi dan revisi pertama adalah berdasarkan hasil evaluasi yang dilakukan oleh review pertama yaitu teman sejawat / guru di SDN 29 Idai dan reviewer kedua adalah ahli Matematika yaitu dosen Program Studi Pendidikan Matematika IKIP PGRI Pontianak. Setelah direvisi dan dilakukan implementasi maka dilakukan revisi kembali untuk mendapatkan modul yang lebih baik.

\section{Hasil dan Pembahasan}

Modul Etnomatematika Berbasis Budaya Dayak dengan Pendekatan Joyfull Learning digunakan sebagai bahan ajar siswa saat kegiatan Luring selama masa Pandemi Covid-19 yang dilakukan di SD Negeri 29 Idai, Kabupaten Sintang. Modul Etnomatematika dikembangkan berdasarkan hasil studi literasi dan pengumpulan dokumentasi kegiatan masyarakat Dayak di Desai Idai, Kecamatan Ketungau Hulu, Kabupaten Sintang, Provinsi Kalimantan Barat. Setelah modul etnomatematika berbasis budaya Dayak dengan pendekatan joyfull learning selesai disusun oleh peneliti, selanjutnya peneliti melakukan 
evaluasi dengan meminta masukan dan saran kepada rekan sejawat dan mendapatkan masukan dari dosen Program Studi Pendidikan Matematika IKIP PGRI Pontianak sebagai reviewer pakar ahli di bidang matematika. Ada pun desain cover modul etnomatematika dapat dilihat pada gambar 1.

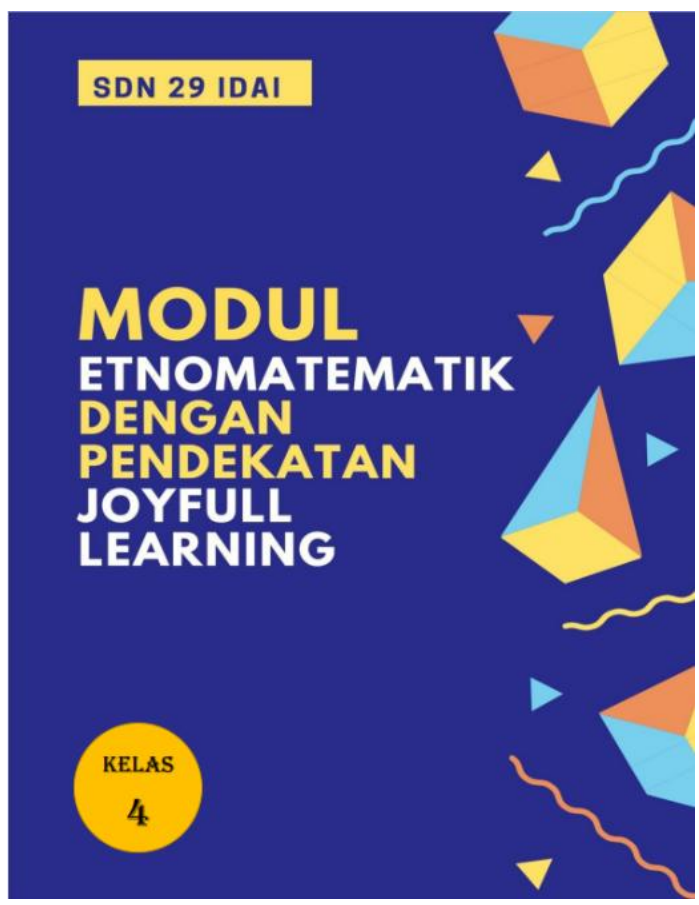

Gambar 1. Desain Cover Modul Etnomatematika Berbasis Budaya Dayak dalam Pembelajaran Matematika dengan Pendekatan Joyfull Learning

Sebelum digunakan oleh siswa untuk belajar, peneliti meminta rekan sejawat dan dosen Program Studi Pendidikan Matematika IKIP PGRI Pontianak untuk memvalidasi modul. Hal ini dilakukan untuk mendapatkan masukan terkait konsep-konsep matematika dalam kehidupan sehari-hari masyakat Dayak yang digunakan sebagai bahan pembelajaran, serta konsep literasi numerasi. Hasil penilaian reviewer dapat dilihat pada tabel 1. 
Tabel 1. Hasil Validasi Aspek Kelayakan Isi Modul Etnomatematika

\begin{tabular}{|c|c|c|c|c|c|}
\hline \multirow{2}{*}{$\begin{array}{l}\text { Indikator } \\
\text { Penilaian }\end{array}$} & \multirow{2}{*}{ Butir Penilaian } & \multicolumn{2}{|c|}{ Reviewer } & \multirow{2}{*}{$\begin{array}{l}\text { Total Hasil } \\
\text { Penilaian }\end{array}$} & \multirow[t]{2}{*}{$\%$} \\
\hline & & 1 & 2 & & \\
\hline \multirow{3}{*}{$\begin{array}{l}\text { Kesesuaian } \\
\text { materi dengan } \\
\text { KI \& KD }\end{array}$} & $\begin{array}{l}\text { Kelengkapan } \\
\text { materi }\end{array}$ & 3 & 3 & \multirow[t]{3}{*}{19} & \multirow[t]{3}{*}{$79.17 \%$} \\
\hline & Keluasan materi & 3 & 4 & & \\
\hline & $\begin{array}{l}\text { Kedalaman } \\
\text { Materi }\end{array}$ & 3 & 3 & & \\
\hline \multirow[t]{7}{*}{$\begin{array}{l}\text { Keakuratan } \\
\text { Materi }\end{array}$} & $\begin{array}{l}\text { Keakuratan } \\
\text { Konsep dan } \\
\text { definisi }\end{array}$ & 3 & 3 & & \\
\hline & $\begin{array}{l}\text { Keakuratan data } \\
\text { dan fakta }\end{array}$ & 4 & 4 & \multirow[t]{6}{*}{50} & \multirow[t]{6}{*}{$89.29 \%$} \\
\hline & $\begin{array}{l}\text { Keakuratan } \\
\text { contoh dan kasus }\end{array}$ & 4 & 4 & & \\
\hline & $\begin{array}{l}\text { Keakuratan } \\
\text { gambar, diagram, } \\
\text { dan ilustrasi }\end{array}$ & 4 & 4 & & \\
\hline & $\begin{array}{l}\text { Keakuratan } \\
\text { istilah-istilah }\end{array}$ & 4 & 3 & & \\
\hline & $\begin{array}{l}\text { Keakuratan } \\
\text { notasi, simbol, } \\
\text { dan ikon }\end{array}$ & 4 & 3 & & \\
\hline & $\begin{array}{l}\text { Keakuratan } \\
\text { acuan pustaka }\end{array}$ & 3 & 3 & & \\
\hline \multirow[t]{4}{*}{$\begin{array}{c}\text { Kemutakhiran } \\
\text { Materi }\end{array}$} & $\begin{array}{l}\text { Kesesuaian } \\
\text { materi dengan } \\
\text { ilmu Matematika }\end{array}$ & 3 & 3 & \multirow[t]{4}{*}{26} & \multirow[t]{4}{*}{$81.25 \%$} \\
\hline & $\begin{array}{l}\text { Kesesuaian } \\
\text { materi dengan } \\
\text { contoh dan kasus } \\
\text { dalam kehidupan } \\
\text { sehari-hari }\end{array}$ & 4 & 3 & & \\
\hline & $\begin{array}{l}\text { Gambar, } \\
\text { diagram, ilustrasi } \\
\text { dalam kehidupan } \\
\text { sehari-hari }\end{array}$ & 4 & 3 & & \\
\hline & $\begin{array}{l}\text { Kemutakhiran } \\
\text { Pustaka }\end{array}$ & 3 & 3 & & \\
\hline $\begin{array}{l}\text { Mendorong } \\
\text { Keingintahuan }\end{array}$ & $\begin{array}{l}\text { Mendorong rasa } \\
\text { ingin tahu }\end{array}$ & 4 & 4 & 14 & $87.50 \%$ \\
\hline
\end{tabular}




\begin{tabular}{lll}
\hline $\begin{array}{l}\text { Menciptakan } \\
\text { kemampuan } \\
\text { bertanya }\end{array}$ & 3 & 3 \\
\hline
\end{tabular}

Hasil penilaian reviewer terhadap aspek kelayakan kajian pada modul etnomatematika yang dikembangkan dapat dilihat pada tabel 2 .

Tabel 2. Hasil Validasi Kelayakan Penyajian Modul Etnomatematika

\begin{tabular}{|c|c|c|c|c|c|}
\hline \multirow{2}{*}{$\begin{array}{l}\text { Indikator } \\
\text { Penilaian }\end{array}$} & \multirow[t]{2}{*}{ Butir Penilaian } & \multicolumn{2}{|c|}{ Reviewer } & \multirow{2}{*}{$\begin{array}{l}\text { Total Hasil } \\
\text { Penilaian }\end{array}$} & \multirow[t]{2}{*}{$\%$} \\
\hline & & 1 & 2 & & \\
\hline \multirow[t]{2}{*}{$\begin{array}{c}\text { Teknik } \\
\text { Penyajian }\end{array}$} & $\begin{array}{l}\text { Konsistensi } \\
\text { sistematika sajian } \\
\text { dalam kegiatan } \\
\text { pembelajaran }\end{array}$ & 3 & 3 & 12 & $75.00 \%$ \\
\hline & Keruntutan konsep & 3 & 3 & & \\
\hline \multirow[t]{7}{*}{$\begin{array}{l}\text { Pendukung } \\
\text { Penyajian }\end{array}$} & $\begin{array}{l}\text { Soal latihan sesuai } \\
\text { kegiatan } \\
\text { pembelajaran }\end{array}$ & 4 & 3 & 41 & $73.21 \%$ \\
\hline & $\begin{array}{l}\text { Kunci jawaban soal } \\
\text { latihan }\end{array}$ & 2 & 3 & & \\
\hline & $\begin{array}{l}\text { Umpan balik soal } \\
\text { latihan }\end{array}$ & 2 & 3 & & \\
\hline & Pengantar & 4 & 4 & & \\
\hline & Daftar istilah & 3 & 3 & & \\
\hline & Daftar pustaka & 3 & 3 & & \\
\hline & Rangkuman & 2 & 2 & & \\
\hline $\begin{array}{l}\text { Penyajian } \\
\text { Pembelajaran }\end{array}$ & Keterlibatan siswa & 4 & 4 & 7 & $87.50 \%$ \\
\hline \multirow[t]{2}{*}{$\begin{array}{l}\text { Koherensi dan } \\
\text { keruntutan alur } \\
\text { pikir }\end{array}$} & $\begin{array}{l}\text { Ketertautan antar } \\
\text { kegiatan belajar/ } \\
\text { sub kegiatan belajar }\end{array}$ & 4 & 3 & 14 & $87.50 \%$ \\
\hline & $\begin{array}{l}\text { Keutuhan makna } \\
\text { dalam kegiatan bel- } \\
\text { ajar/ subkegiatan } \\
\text { belajar. }\end{array}$ & 4 & 3 & & \\
\hline
\end{tabular}


Dari tabel 1 diperoleh beberapa informasi yaitu (1) kesesuaian materi dengan Kompetensi Inti dan Kompetensi Dasar sebesar 79,17. Ini dapat diartikan bahwa konsep matematika dalam modul telah sesuai dengan Kompetensi Inti dan Kompetensi Dasar. Hasil yang diperoleh sejalan dengan penelitian Utami, Nugroho, Dwijayanti, \& Sukarno (2018) bahwa Kurikulum 2013 edisi revisi tidak menjadikan unsur budaya sebagai konten yang ditekankan, sehingga perlu dikembangkan modul matematika yang mengintegrasikan budaya agar siswa mudah memahami konsep-konsep matematika. Adapun masukan dari reviewer terhadap indikator kesesuaian materi dengan KI dan KD adalah perlunya dilakukan kajian lebih dalam terhadap konsep-konsep matematika dalam budaya Dayak seperti; budaya pernikahan adat, budaya kerajinan Dayak seperti membuat manik-manik, bentuk dan bangunan geometris dalam budaya adat Dayak yang ada secara umum agar khasanah keilmuan dan literasi budaya anak menjadi lebih baik.

Nilai dari kedua reviewer terhadap keakuratan materi adalah sebesar 89,29\%, menunjukkan hasil yang sangat baik. Hasil tersebut diperoleh karena modul etnomatematika yang dikembangkan telah mengintegrasikan budaya dan keseharian masyarakat Dayak di Desa Idai seperti tradisi manugal yaitu sebuah tradisi menanam padi yang dilakukan oleh masyarakat adat Dayak, tradisi membuat cupai atau tas tradisional masyarakat Dayak. Cupai sering digunakan oleh masyarakat Dayak ketika berladang. Dengan cupai siswa diajak untuk belajar literasi numerasi melalui perhitungan sederhana, seperti menghitung panjang tali cupai, diameter atas cupai, dimeter bawah cupai, luas penampang bawah cupai dan volume cupai, gambar cupai dalam modul dapat dilihat pada gambar 2. Konsep etnomatematika yang diajarkan sejalan dengan penelitian yang dilakukan Haran et al. (2019). Dalam kegiatan merangkai manik, pengrajin Dayak biasanya menggunakan penyebutan perhitungan manik seperti : ji, duak, telok, paat, limak, enam, tusuu' sayaaq, pitaan, dan puluu'. Jika dihubungkan dengan muatan matematika, maka termasuk 
dalam konsep membilang. Hal senada disampaikan Fajriyah (2018) bahwa etnomatematika berperan dalam mendukung literasi matematika dengan memfasilitasi siswa untuk mampu mengonstruksi konsep matematika sebagai bagian dari literasi matematika berdasarkan pengetahuan siswa tentang lingkungan sosial budaya mereka.
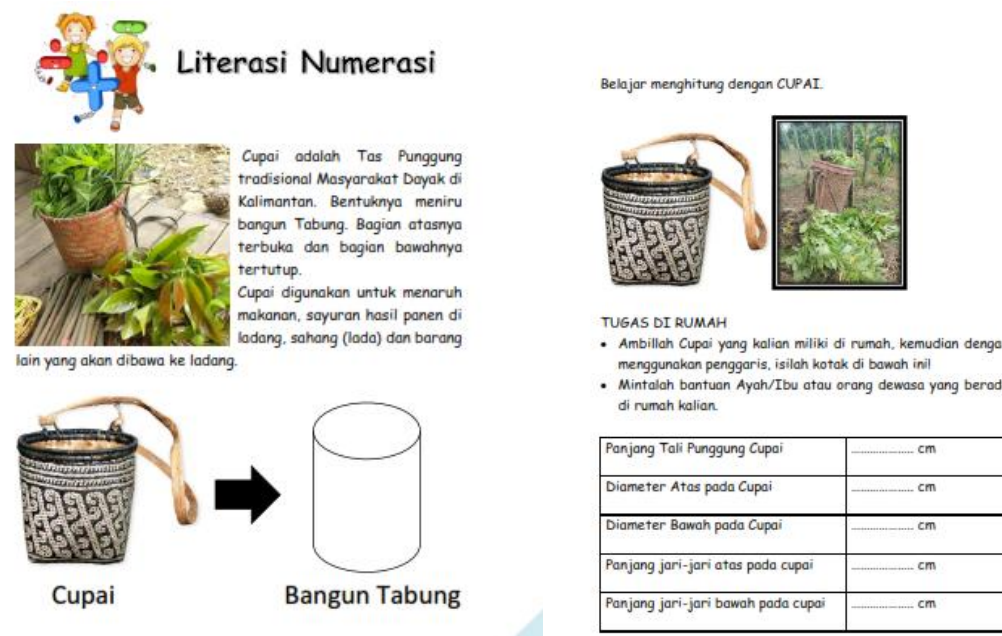

Gambar 2. Integrasi Budaya Dayak dalam Modul Etnomatematika

Gambar dan ilustrasi dalam modul etnomatematika berasal dari hasil foto dan dokumentasi yang dilakukan peneliti terhadap kegiatan keseharian masyarakat Dayak di Desa Idai, Kecamatan Ketungau Hulu, Kabupaten Sintang, Provinsi Kalimantan Barat. Sehingga hasil dari kedua reviewer diperoleh nilai sebesar $81,25 \%$, sedangkan, hasil kedua reviewer untuk indikator mendorong keingintahuan menunjukkan hasil sebesar 87,50\%. Melalui modul etnomatematika yang dikembangkan dapat diketahui bahwa modul akan mampu untuk mendorong rasa ingin tahu siswa serta keaktivannya dalam berusaha untuk menjawab pertanyaan yang ada pada modul. 
Hasil validasi kelayakan penyajian modul etnomatematika berbasis budaya Dayak dengan pendekatan joyfull learning dari kedua reviewer adalah sebagai berikut. (1) Teknik penyajian sebesar $75,00 \%$; (2) Pendukung penyajian sebesar $73,21 \%$; (3) Penyajian pembelajaran $87,50 \%$; (4) Kohereni dan keruntutan alur piker memperoleh nilai sebesar $87,50 \%$. Hasil penyajian menunjukkan hasil yang masih kurang yaitu hanya sebesar 73,21\% sehingga perlu dilakukan revisi dengan memperbanyak soal latihan, membuat soal umpan balik dalam bentuk latihan soal, menambahkan daftar pustaka, dan menuliskan daftar istilah sehingga siswa dapat memahami kosakata-kosakata penting matematika dan kosakata lainnya yang perlu mendapatkan penjelasan lebih rinci. Rangkuman yang merupakan inti dari materi subpokok bahasan perlu dibuat lebih menarik. Temuan dan masukan dari reviewer menjadi bahan masukan dalam pengembangan modul etnomatematika.

Berdasarkan hasil evaluasi penerapan pembelajaran menggunakan modul etnomatematika berbasis budaya Dayak dengan pendekatan joyfull learning diperoleh hasil sebagai berikut. (1) Siswa belum dapat memahami soal cerita yang terlalu panjang, sehingga siswa salah menjawab soal yang diberikan; (2) Siswa mudah memahami dan menjawab dengan benar jika pada soal diberika ilustrasi atau gambar. Hal ini menunjukkan bahwa konsep matematika akan lebih mudah dipahami jika disertai dengan gambar, seperti gambar cupai, gambar rumah Dayak, gambar tikar/bidai. Hasil yang diperoleh senada dengan hasil penelitian Richardo (2017) bahwa melalui pembelajaran etnomatematika, maka lingkungan pembelajaran matematika yang biasanya terbatas di dalam kelas menjadi pembelajaran di luar kelas, sehingga tercipta motivasi yang positif dan pembelajaran matematika menjadi menyenangkan. Hasil tersebut sejalan dengan penelitian Prinotama, et al (2019) bahwa pembelajaran dengan Joyfull Learning berpengaruh terhadap motivasi belajar siswa pada mata pelajaran IPS di SDN Karah I Surabaya sehingga dapat meningkatkan hasil belajar siswa. Hal ini dapat dilihat berdasarkan hasil uji Independent 
Sample T-test hasil nilai Prinotama, et al (2019) motivasi kelas kontrol dan kelas eksperimen, sebesar $=5,873$, untuk motivasi belajar dengan metode pembelajaran Joyfull Learning. Hal itu juga ditunjukkan dengan nilai ratarata (mean) pada kelas eksperimen yaitu sebesar 63,3 lebih besar jika dibandingkan dengan nilai rata-rata (mean) pada kelas kontrol yaitu sebesar 54,2. Dengan tingkat signifikan $0,000<a(0,05)$. Maka dapat disimpulkan bahwa ada pengaruh metode pembelajaran berbasis joyfull learning terhadap motivasi belajar siswa pada mata pelajaran IPS di SDN Karah I Surabaya.

\section{Penutup}

Berdasarkan hasil penelitian dan pembahasan yang telah dipaparkan dapat disimpulkan bahwa modul etnomatematika berbasis budaya Dayak dengan pendekatan joyfull learning mendapatkan hasil yang baik, sehingga dapat digunakan untuk mengajarkan konsep matematika bagi siswa kelas 4 di SDN 29 Idai, Kabupaten Sintang. Namun, disarankan untuk lebih mengeksplor kebudayaan-kebudayaan Dayak maupun kebudayaan lainnya seperti kebudayaan Melayu, Jawa, dan lainnya yang berkaitan dengan konsep-konsep matematis mulai dari keseharian maupun upacara adat, sehingga diharapkan modul dapat digunakan secara nasional.

\section{Ucapan Terima Kasih}

Penulis mengucapkan terima kasih kepada rekan-rekan sejawat di SDN 29 Idai, Pengawas dan Kepala Dinas Pendidikan Kabupaten Sintang serta Program Studi Pendidikan Matematika IKIP PGRI Pontianak. 


\section{Daftar Referensi}

Anugrahana, A. (2020). Hambatan, Solusi dan Harapan: Pembelajaran Daring Selama Masa Pandemi Covid-19 Oleh Guru Sekolah Dasar. Scholaria: Jurnal Pendidikan Dan Kebudayaan, 10(3), 282-289.

Apriyono, F., Rosyidah, E. A., Purnomo, T., Sulityo, J., Munir, M. M., \& Safitri, V. W. (2019). Eksplorasi Ethnomatematika pada Permainan Tradisional Egrang di Tanoker Ledokombo Jember. SIGMA, 4(2), 51-58.

Fajriyah, E. (2018). Peran Etnomatematika Terkait Konsep Matematika dalam Mendukung Literasi. PRISMA 1, Prosiding Seminar Nasional Matematika 1, 1, 114-119. Retrieved from https://journal.unnes.ac.id/sju/index.php/prisma/

Firmansyah, F., \& Haris, H. (2019). Pengembangan Bahan Ajar Matematika SD Bernuansa Ethnomatematika Masyarakat di Bumi Hibualamo. Hibualamo: Seri Ilmu-Ilmu Sosial Dan Kependidikan, 3(2), 14-22. Retrieved from http://journal.unhena.ac.id

Haran, A., Hartoyo, A., \& Sayu, S. (2019). Etnomatematika dalam Merangkai Manik Masyarakat Dayak Kayaan Kapuas Hulu. Jurnal Pendidikan Dan Pembelajaran, 8(3), 1-8. Retrieved from https://jurnal.untan.ac.id/index.php/jpdpb/article/view/31952

Hartoyo, A. (2012). Eksplorasi Etnomatematika pada Budaya Masyarakat Dayak Perbatasan Indonesia-Malaysia Kabupaten Sanggau Kalbar. Jurnal Penelitian Pendidikan, 13(1), 14-23. Retrieved from http://jurnal.upi.edu/penelitianpendidikan/view/1387/eksplorasi-etnomatematika-pada budaya-masyarakat-dayak-perbatasan-indonesia-malaysia kabupaten-sanggau-kalbar-.html

Krishna, I. P. D. M. K., Agustini, K., \& Tegeh, I. M. (2018). Pengembangan Konten Dynamic E-Learning Berstrategi Flipped Classroom pada mata pelajaran Simulasi Digital Kelas X di SMKN 2 Singaraja. Jurnal Teknologi Pembelajaran Indonesia, 8(3), 66-74. Retrieved from https://doi.org/10.23887/jtpi.v8i3.2607

Muhammad, H. (2020). Menyiapkan Pembelajaran di Masa Pandemi: Tantangan dan Peluang. Kementerian Pendidikan dan Kebudayaan. 
Prayitno, E., Rachmiaszasi, L., \& Kadarwati, S. (2017). Ethnomatematika Pendidikan Dasar. Jurnal Karya Pendidikan Matematika, 4(2), 19-24.

Prinotama, A. N., Larasati, D. A., \& Roosyanti, A. (2019). Pengaruh Joyfull Learning terhadap Motivasi Belajar di SDN Karah I Surabaya. Jurnal Pendidikan Dasar, 1(1), 96-105.

Richardo, R. (2017). Peran Ethnomatematika dalam Penerapan Pembelajaran Matematika pada Kurikulum 2013. LITERASI (Jurnal Ilmu Pendidikan), 7(2), 118-125.

Surat Edaran Kemendikbud No. 4 Tahun 2020. Pembatalan Ujian Nasional dan Kebijakan Pendidikan Pada Masa Darurat Covid-19. (Online),

(http:/ /pmplampung.kemdikbud.go.id/detailpost/surat-edaranmendikbud-no-4-tahun-2020-mengenai-pembatalan-ujiannasional-dan-kebijakan-pendidikan-pada-masa-darurat-covid-19), diakses 28 Januari 2021.

Tegeh, I. M. (2020). Penelitian Pengembangan (Research \& Development. Jurnal Pendidikan, 49.4 Retrieved from https://id.wikipedia.org/wiki/Kuliah_online

Utami, R. E., Nugroho, A. A., Dwijyanti, I., \& Sukarno, A. (2018). Pengembangan E-Modul Berbasis Etnomatematika untuk Meningkatkan Kemampuan Pemecahan Masalah. JNPM (Jurnal Nasional Pendidikan Matematika), 2(2), 268. https://doi.org/10.33603/jnpm.v2i2.1458 